\title{
Estimating the Return of Higher Education in Algeria: Evidence From Adrar University
}

\author{
Benlaria Houcine ${ }^{1}$, Mostéfaoui Sofiane ${ }^{2}$ \\ ${ }^{1}$ Department of Economics, University of Adrar, Algeria \\ ${ }^{2}$ Department of Management, University of Adrar, Algeria \\ Correspondence: Mostéfaoui Sofiane, Department of Management, University of Adrar, Algeria.
}

Received: February 6, 2018

Accepted: March 12, $2018 \quad$ Online Published: March 18, 2018

doi:10.11114/jets.v6i4.3116

URL: https://doi.org/10.11114/jets.v6i4.3116

\begin{abstract}
This study aims to measure the individual rate of return for investment in higher education at Adrar University by using both basic and extended Mincerian Earnings Function. In addition to this, the comparison had been established between the results obtained and those of other researches in the same domain.

We adopted in the research the model of Mincer in evaluating the rate of the economic returns according to previous classifications and the effective experience got by the individual in the work (measured by years). The result of the model application states that the economic return of university education in Algeria has been improved by $8.49 \%$ based on the benchmark of Psacharopoulos International Return measured by $9.8 \%$.

We conclude that there is no general trend by which we can interpret the results but this lack of interpretation refers to the typical situation of the Algerian economy and its impact on the human capital (education specifically) as it is known that the relationship between the economic development and the human development is positive.
\end{abstract}

Keywords: economic return of the university education, the individual economic return, effective experience

\section{Introduction}

Countries over the world paid particular attention to the education sector in general and higher education in particular, in order to achieve their objectives. These goals consist principally of the community service and upgrading its civilization height, as well as providing the state by the different specialists, technicians and experts in various fields (Richard Raymond and Michael Sesnowitz, 1975; Walter W. McMahon, 1975; Jane Louise Johnson, 1978; Gary Rhoades, 1983; Kent Hill et al, 2005; Sandy Baum \& Kathleen Payea, 2005). Therefore, the university could be considered as the main source of investment as the human wealth is considered as the most important and expensive fortunes of a society (David Post et al, 2004; Joy Murray, 2007; Christian Schierenbeck, 2013).

Due to the growing doubts about the feasibility of investment in higher education especially after an outbreak of some negative unforeseen consequences resulting from this type of investment, as well as the large amount of resources spent; necessary attempts have been made to evaluate the investment in higher education (Albert J. Robinson, 1971; Walter W. McMahon; 1974; B. M. Craven et al, 1983; Rajesh Kumar Sharma, 2006). These endeavors are coupled with the view of some economists that the evaluation of the investment in higher education is difficult and distinguished from the other approaches undertaken to evaluate other kinds of investments (Daniel C. Rogers, 1972; Briggs P. Dunn and W. Robert Sullins, 1982; Donald R. Winkler, 1984; Kathy L. Stafford et al, 1984). The intricacy refers intrinsically to the multiplicity of objectives and the presence of a large scale of non economic returns. However, this picture might not discourage the ongoing processes to monitor and assess this type of investments (Jandhyala B. G. Tilak, 1995; D. F. Westerheijden, 1999; Adela Garcia Aracil and Davinia Palomares- Montero, 2010; Olga Cherednichenko and Olga Yangolenko, 2013).

In this context, the measurement of the return on investment in education presents the focus of the economic vision for the sector of education and the way to assess the feasibility of investing in this important arena for both the individual and social levels (Edwared F. Renshaw, 1960; Raymond P. Byron and Evelyn Q. Manaloto, 1990; Julie McMillan and John Western, 2000; Axel Muller-Hofvenschitild, 2001; Berthold U. Wigger, 2004; M. N. Van Den Berg and W. H. A. Hoffman, 2005; Laveesh Bhandari and Mridusmita Bordoloi, 2006; Pedro Carneiro, James J. Heckman and Edward J. 
Vytlacil, 2011). The objective of the measurement approach is to rationalize the economic and educational decisions in the community (Jesse M. Cunda and Trey Miller, 2014; Khanchitpol Yousapronpaiboon, 2014). In this context, the famous model presented by Mincer (1974) called 'Mincerian Earnings Function,' made possible the estimation of the rates of return to education within and cross-countries.

\section{The Sample of the Study}

The models of Return-to-Education studies in several countries were based on the statistical approvals undertaken by the official authorities in the country, the fact that facilitates the analyses processes undertaken by the researchers. To examine the issue, we adopted in this study a questionnaire including 450 distributed copies and 302 retrieved ones.

The results of the table below show that the average years of study for the total sample is estimated by $15.98 \%$ and for males and females by $15.97 \%$ and $15.98 \%$ respectively:

Table 1. Mean of the Study Years

\begin{tabular}{c|ccc}
\hline & Total Sample & Males & Females \\
\hline Mean of the Years & 15.98 & 15.97 & 15.98 \\
Observations & 302 & 152 & 150 \\
\hline
\end{tabular}

Additionally, the following table presents the means of the ages for the males and females of the study. It indicates clearly the mean ages of females and males are nearly the same.

Table 2. Mean of the Study Ages

\begin{tabular}{c|ccc}
\hline & Total Sample & Males & Females \\
\hline Mean of the Ages & 32 & 33.42 & 31.05 \\
Observations & 302 & 152 & 150 \\
\hline
\end{tabular}

The average of per capita income of the total sample was estimated by 58794.7 DZD. The classification of the sample by sex reveals that the average per capita of the males' income is estimated by 59894.74 DZD higher than of females estimated by 57680.00 DZD:

Table 3. Mean of the per capita incomes

\begin{tabular}{c|ccc}
\hline & Total Sample & Males & Females \\
\hline $\begin{array}{c}\text { Mean of per capita income } \\
\text { (DZD) }\end{array}$ & 60794.7 & 61894.74 & 59680.00 \\
Observations & 302 & 152 & 150 \\
\hline
\end{tabular}

Years of theoretical experience according to the Mincer methodology is defined by the age minus the years of education minus the predefined age for enrollment in the educational system (usually 6 years). This rate is measured in the study by $111.98 \%$ as it is shown by the table:

Table 4. Mean of Practical and Theoretical Years

\begin{tabular}{c|cccc}
\hline & $\begin{array}{c}\text { Theoretical } \\
\text { Experience }\end{array}$ & $\begin{array}{c}\text { Practical } \\
\text { Experience }\end{array}$ & $\begin{array}{c}\text { Difference of } \\
\text { Experience }\end{array}$ & Rate of Increase \\
\hline Total Sample & 10.26 & 4.84 & 5.42 & 111.98 \\
Males & 11.45 & 5.38 & 6.07 & 112.82 \\
Females & 9.07 & 4.3 & 4.77 & 110.93 \\
\hline
\end{tabular}

\section{Model Specification}

Mincer (1958) had developed the human capital theory by which the measurement of the rate of return on human capital had been applied. It is important to recall that the incentive to develop the human capital approach was to try to understand the role of individual decisions on the basis of economic behavior in interpreting wage inequality, as opposed to income distribution theories that consider such behavior outside the scope of analysis. Human capital models focus on human capital investment decisions by excluding all non-competitive forces with varying incomes. The basic assumptions of the model as developed by Mincer are:

- That the length of the training period or education is the main source of inequality in the incomes of workers and as well as it increases the worker's productivity. However, the training process requires a delay in income for a future period

- In making a decision on training, individuals are expected to obtain higher incomes in the future to compensate for the cost of training

- The cost of training should be limited to the opportunity cost of the income which means the income that would have been earned by the individual if he had not enrolled in the training institutions

- It is assumed that individuals do not decide to take future training after the completion of the first training period and the future income flows still remain constant even after the end of the first training period 
- The interest rate used by individuals in determining future flows is assumed to be constant.

The literature is abundant by different studies that measured the rates of return on education based on the theoretical approach as well practical one. The analyses reveal most common applied method in this field that tackle the estimation of the functions based on the dependent variable (logarithm of wages or income), and the independent variable is represented by the years spend in education enrollment as it is shown by the following model:

$$
\begin{aligned}
& \log y_{i}=\alpha+\beta S_{i}+\delta X_{i}-\gamma E X^{2}-\mu \ldots \ldots \ldots \\
& \log y_{i}=\alpha+\sum \beta_{k} D_{k}+\delta E X_{i}-\gamma E X_{i}^{2}+v_{i}
\end{aligned}
$$

Where $E X$ indicate the years of theoretical experience; $\alpha$ is a constant indicating the logarithm income of newly hired workers who have not received any education; $\beta$ is the coefficient of years of schooling and in this case reflects the rate of personal return on education. The previous function assumes that the relationship between years of education and wage logarithms is linear. In other words, each additional year of education has the same return regardless of the level of education, while assuming that this relationship is nonlinear for years of experience. The return on years of experience is expected to be positive but decreases over time (negative sign).

In order to estimate the rate of return of higher education in Algeria, and in line with the requirements of the study, we adopt the Basic Earnings Function developed by Mincer (1974). The software used in the estimation process is EVIEWS 8.0. The results are represented by the following table:

Table 5. Estimation of Mincer Model according to the Theoretical Experience

\begin{tabular}{c|ccc}
\hline Independent Variable & Total Sample & Males & Females \\
\hline Constant $(\alpha)$ & 9.3688 & 8.2626 & $\mathbf{1 0 . 5 0 1 6}$ \\
& $(22.8405)$ & $(13.2565)$ & $\mathbf{( 1 5 . 7 3 6 2 )}$ \\
Years of Study $(\beta)$ & 0.1036 & 0.1729 & $\mathbf{0 . 0 3 5 8}$ \\
Years of Theoretical & $(3.9789)$ & $(4.4545)$ & $\mathbf{( 0 . 8 5 5 1 )}$ \\
Experience $(\delta)$ & -0.0178 & -0.0159 & $\mathbf{0 . 0 3 7 0}$ \\
Years of Theoretical & $(-1.2853)$ & $(-0.7976)$ & $\mathbf{( - 1 . 6 3 2 3})$ \\
Experience (Square $\gamma)$ & 0.0010 & 0.0009 & $\mathbf{0 . 0 0 2 2}$ \\
$R^{2}$ & $(1.7249)$ & $(1.2091)$ & $\mathbf{( 1 . 9 5 7 9 )}$ \\
Fisher Test $F$ & 13.5734 & 23.3050 & $\mathbf{1 0 . 3 0 0 9}$ \\
Observations $N$ & 7.6955 & 7.2927 & 2,7178 \\
\hline
\end{tabular}

By estimating the return function presented by equation 01 via the OLS method (Table 5), it is revealed that the special rate of return for the total sample, male and female are: $10.36 \%, 17.29 \%$ and $3.58 \%$, respectively. In addition to this, the values of Student test of $(\mathrm{t})$ indicate the significance of the constant parameter $\mathrm{C}$ and the coefficient of the years of study B, as well as the non-significance of the years of experience their squares. These observations are added to those related to the low explanatory capacity in the three cases in which R2 takes the values of $13.57 \%, 23.30 \%, 10.30 \%$ for the total sample, males and females respectively. On the other hand, the values of the Fisher statistic indicate that the model is statistically acceptable, and that the explanatory variables explain the level of the income logarithm (in the case of the total sample and the males) despite the fact that the coefficient of determination is low. The value of the Fisher statistic in the case of females indicates that the model is not accepted statistically, but unlike the model assumptions, the return on years of experience was negative and increasing over time (negative sign).

Based on these results, we cannot rely on years of theoretical experience to interpret the income variation because they are irrational, especially in the case of Algeria. This fact is due to:

- The decrease of the age average of the studied sample in the three cases: 32.03, 33.42 and 31.05, respectively

- The high rate of unemployment or that of the time spent by the unemployed graduates

- The neglect of the period of the military service

-The high level of economic waste represented by the number of years of decline

- Not taking into account the turnover rate

These and other factors have had a significant impact on the difference between the average of the theoretical and the practical experience. This difference exceeds the practical experience per se. For this reason, we will rely on years of 
practical experience in estimating the rate of return rather than the theoretical one:

Table 6. Estimation of Mincer Model according to the practical Experience

\begin{tabular}{|c|c|c|c|c|c|c|c|}
\hline $\begin{array}{c}\text { Independent } \\
\text { variable }\end{array}$ & $\begin{array}{c}\text { Constant } \\
\alpha\end{array}$ & $\begin{array}{l}\text { Years of } \\
\text { Study } \beta\end{array}$ & $\begin{array}{c}\text { Years of } \\
\text { Practical } \\
\text { Experience } \delta\end{array}$ & $\begin{array}{l}\text { Square of } \\
\text { Practical } \\
\text { Years } \gamma\end{array}$ & $R^{2}$ & $\begin{array}{c}\text { Fisher Test } \\
F\end{array}$ & $\begin{array}{c}\text { Observations } \\
N\end{array}$ \\
\hline $\begin{array}{c}\text { Total } \\
\text { Sample }\end{array}$ & $\begin{array}{c}9.5184 \\
(24.1955) \\
*\end{array}$ & $\begin{array}{c}0.0849 \\
(3.5178) \\
*\end{array}$ & $\begin{array}{c}0.0247 \\
(2.3835) \\
*\end{array}$ & $\begin{array}{c}-0.0008 \\
(-1.1785) \\
* *\end{array}$ & $\begin{array}{c}16.519 \\
4\end{array}$ & $\begin{array}{c}9.696 \\
2\end{array}$ & 151 \\
\hline
\end{tabular}

* Significant at 95\% ** Non-significant

Through the replacement of the practical experience by the theoretical one, the rate of return represents lower results from $1.87 \%$ to $8.49 \%$ for the total sample. Thus, every additional year spent in higher education leads to an increase in monthly wage by $8.49 \%$.In accordance with the model assumptions, the return on years of experience is positive and decreasing over time (negative). This is an important result because it highlights the bias on the return rate which is due to the inaccuracy and complexity of the two variables.

The values of Fisher test indicate the significance of the model as a whole and its appropriateness to explain the issue despite the low explanatory power of the model presented by $\mathrm{R}^{2}$.

Table 7. Return Rate by Sex

\begin{tabular}{c|cc}
\hline Independent Variable & Males & Females \\
\hline Constant $\alpha$ & 7.9883 & $(10.0614$ \\
Years of Study $\beta$ & $(12.9831)^{*}$ & $0.0500)^{*}$ \\
& 0.1820 & $(1.2929)^{* * *}$ \\
Years of Practical Experience $\delta$ & $(4.8312)^{*}$ & 0.0297 \\
& 0.0133 & $(2.0785)^{*}$ \\
Square of Practical Experience $\gamma$ & $(0.8571)^{* *}$ & -0.0013 \\
$R^{2}(\%)$ & 0.0003 & $(-1.1485)^{* *}$ \\
Fisher Test $F$ & $(0.3449)^{* *}$ & 14.1180 \\
Observations $N$ & 30.4142 & 3.8905 \\
\hline
\end{tabular}

*Significant at $95 \% \quad * *$ Non-significant

The above table indicates that the rate of return on education in males is higher than that of females $(18.20 \%$ for males versus $5 \%$ for females).

Table 8. Rate of Return by Residence

\begin{tabular}{|c|c|c|}
\hline Independent Variable & Rural & Urban \\
\hline $\begin{array}{c}\text { Constant } \alpha \\
\text { Years of Study } \beta\end{array}$ & $\begin{array}{c}8.9153 \\
(12.7347)^{*} \\
0.1225 \\
(2.8159)^{*}\end{array}$ & $\begin{array}{c}9.7349 \\
(20.6193)^{*} \\
0.0710 \\
(2.4613)^{*}\end{array}$ \\
\hline Years of Practical Experience $\delta$ & $\begin{array}{c}0.0289 \\
(1.0070)^{* *}\end{array}$ & $\begin{array}{c}\text { 0.0289 } \\
(2.3495)^{* *}\end{array}$ \\
\hline Square of Practical Experience $\gamma$ & $\begin{array}{c}-0.0022 \\
(-0.8297)^{* *}\end{array}$ & $\begin{array}{c}-0.0009 \\
(-1.1824) * *\end{array}$ \\
\hline $\begin{array}{cc}R^{2}(\%) \\
\text { Fisher Test } \\
\text { Observations }\end{array}$ & $\begin{array}{c}18.3991 \\
2.8560 \\
42 \\
\end{array}$ & $\begin{array}{c}17.1267 \\
7.2331 \\
109 \\
\end{array}$ \\
\hline
\end{tabular}

*Significant at $95 \% \quad * *$ Non-significant

The determination of the Mincer function by residence shows that the rate of return from higher education in urban areas is lower than the rate of return in rural areas (7.10\% in urban areas and $12.25 \%$ in rural areas). This result does not fit with the international standards.

\section{Discussion of the Results}

The following table shows the different results of the return rate of higher education for this study. The results are related to the total sample by sex, place of residence and specializations: 
Table 9. Results of the Return Rate Estimation from Higher Education

\begin{tabular}{|c|c|c|c|c|c|}
\hline \multirow[t]{2}{*}{ Indicator } & Total Sample & \multicolumn{2}{|r|}{$\operatorname{Sex}$} & \multicolumn{2}{|c|}{ Place of Residence } \\
\hline & & & Female & Rural & Urban \\
\hline $\begin{array}{c}\text { Rate of Return } \\
(\%)\end{array}$ & 8.49 & 18.20 & 5.00 & 12.25 & 7.10 \\
\hline Observations & 151 & 76 & 75 & 42 & 109 \\
\hline $\begin{array}{c}\text { Total } \\
\text { Observations } \\
N\end{array}$ & 151 & & 151 & & 151 \\
\hline
\end{tabular}

The most important results of the estimation process of the Mincer Equation can be summarized as follow:

- The rate of return for the total sample is $8.49 \%$. It is close to the rate of return that Psacharopoulos got in his study which is $9.7 \%$. The latter is close to $10 \%$ as the international standard in this field.

- The rate of return from higher education for males (18.20\%), which is much higher than the rate of return for females (5.00\%), the gap between them is about $13.20 \%$ on average. This result corresponds to the results of international studies as the rate of return for males exceeds his peers In the following regions: European countries in transition (17.5\%), Latin America (13.4\%) and sub-Saharan Africa (12.5\%). This is quite the opposite of the rate of return for females in the regions: Latin America (12.3\%) and Sub-Saharan Africa (8.7\%). However, these results highlight the important fact that the role of women in the economic growth is low. This is due to a number of factors. The most important one is the low social awareness in these areas. In addition to the negative view of the role of women in economic activity as well as the influence of customs and traditions.

- The rate of return by place of residence is estimated by $12.25 \%$ for the countryside, which is higher than the urban rate of return estimated at $7.10 \%$. These results are not consistent with the international standards. This is due to the fact that the division into rural and urban adopted by the official authorities does not seem accurate.

- After replacing practical experience by theoretical one and recasting the model again, we obtain generally accepted statistical results. However, mention the following:

- The explanatory capacity of the estimated models remains weak and far from the average.

- Some of the estimated models are not compatible with the economic theory related to the Mincerian function especially in males' estimation.

For these reasons, the question arises: how important is the level of academic attainment (s) and the number of years of experience (EX) in interpreting changes in income? To know this, we must pass through the following stages:

First: Estimating the model taking into account the number of years of education (s) as a single explanatory variable of changes in income.

Second: Reconsideration of the model taking years of experience (EX) as a single explanatory variable of changes in income.

Third: At this stage we compare the results we reached in the previous two stages with the results we obtained when estimating the model according to both years of achievement (s) and practical years of experience (EX).

By respecting the previous stages, the following results are mentioned:

For the first stage, the results are: $\mathrm{R} 2=10.9863 \%$, return on education years $(\beta)=65.6710 \%$, Fisher test $(\mathrm{F})=9.1332$

As for the second phase, it is as follow: $\mathrm{R} 2=9.4918 \%$, return on years of experience $(\beta)=1.2088 \%$, Fischer test $(\mathrm{F})=$ 7.7605 .

\section{Conclusion}

The study of the feasibility and evaluation of investment projects requires a rigorous scientific approach to ensure that the decisions taken achieve economic development as long as the natural and material resources are limited, as is the case in Developed countries. In fact; researches about the evaluation of investment in university education in Algeria are still scarce. In light of this, this study comes as an attempt to examine how to evaluate this type of investment in Algeria.

\section{Findings}

-There are many methods and models used to measure the economic return of education. Perhaps the most common is the method of Return-Cost and the methodology of Earning Function of Mincer for accurate results and simple use, despite the criticism received in their right.

-The rate of return at the University of Adrar is $8.49 \%$. This rate is lower than the rate of the global return of (10\%). 
This result calls for a strict assessment of the educational polices adopted.

-There is a correlation between the results of this study with previous studies similar to different countries regarding the values of individual and social rate of return for investment in higher education.

- The results of the empirical study show that government expenditure on higher education in Algeria is generally high, as the involvement of individuals and the private sector in funding the educational process is not entirely present.

\section{Acknowledgements}

The authors express their warm thanks and gratitude to the University of Adrar for the help and support throughout the study.

\section{References}

Berg, M. N. V. D., \& Hoffman, W. H. A. (2005). Student Success in University Education: A multi-measurement Study of the Impact of Student and Faculty Factors on Study Progress, Higher Education, 50, 413-446. https://doi.org/10.1007/s10734-004-6361-1

Bhandari, L., \& Bordoloi, M. (2006). Income Differentials and Returns to Education, Economic and Political Weekly, 41(36), 3893-3900.

Byron, R. P., \& Manaloto, E. Q. (1990). Returns to Education in China, Economic Development and Cultural Change, 38(4), 783-796. https://doi.org/10.1086/451833

Carneiro, P., Heckman, J. J., \& Vytlacil, E. J. (2011). Estimating Marginal Returns to Education, The American Economic Review, 101(6), 2754-2781. https://doi.org/10.1257/aer.101.6.2754

Carven, B. M., Dick, B., \& Wood, B. (1983). Resource Reallocation in Higher Education in Britain, Higher Education, 12(5), 579-589. https://doi.org/10.1007/BF00140381

Cherednichenko, O., \& Yangolenko, O. (2013). Towards Quality Monitoring and Evaluation Methodology: Higher Education Case Study, A paper presented at the 4th International United Information Systems Conference, UNISCON 2012, Ukraine, Springer-Verlag Berlin, Heidelberg, 120-127.

Christian, S. (2013). Fixing Higher Education: A Business Manager's Take on How to boost Productivity in Higher Education, Springer Gabler Research. https://doi.org/10.1007/978-3-658-00213-8

Cunda, J. M., \& Miller, T. (2014). Measuring value-added in higher education: Possibilities and limitations in the use of administrative data, Economics of Education Review, 42, 64-77. https://doi.org/10.1016/j.econedurev.2014.06.001

Dunn, B. P., \& Sullins, W. R. (1982). Cost-Benefit Analysis: Applicability in Higher Education, Journal of Education Finance, 8(1), 20-32.

Erfort, O., Erfort, I., \& Zbarazskaya, L. (2016). Financing Higher Education in Ukraine: The Binary Model versus the Diversification Model, International Journal of Educational Development, 49, 330-335. https://doi.org/10.1016/j.ijedudev.2016.03.009

Garcia-Aracil, A., \& Palomares-Montero, D. (2010). Examining Benchmark Indicator Systems for the Evaluation of Higher Education Institutions, High Educ., 60, 217-234. https://doi.org/10.1007/s10734-009-9296-8

George, P. (1995). The Profitability of Investment in Education: Concepts and Methods, Working Paper, Human Capital Development and Operations Policy, 1-22.

Hill, K., Hoffman, D., \& Rex, T. R. (2005). The Value of Higher Education: Individual and Societal Benefits, W. P. Carey School of Business Arizona State University

Jandhyala, B. G. T. (1995). Funding Higher Education in India, Economic and Political Weekly, 30(9), 426-429.

McMahon, W. W. (1974). Policy Issues in the Economies of Higher Education and Related Opportunities in Britain and the United States, Higher Education, 3(2), 165-185. https://doi.org/10.1007/BF00143790

McMahon, W. W. (1975). Economic and Demographic Effects on Investment in Higher Education, Southern Economic Journal, 41(3), 506-514. https://doi.org/10.2307/1056161

McMahon, W. W., \& Wagner, A. P. (1981). Expected Returns to Investment in Higher Education, The Journal of Human Resources, 16(2), 274-285. https://doi.org/10.2307/145512

McMillan, J., \& Western, J. (2000). Measurement of the Socio-Economic Status of Australian Higher Education Students, Higher Education, 39, 223-248. https://doi.org/10.1023/A:1003943824357

Murray, J. (2007). The Wider Social Benefits of Education: A Research report, Centre for Integrated Sustainability 
Analysis, 1-23.

Philippe, de V., Martou, F., \& Vandenberghe, V. (1996). Cost-Benefit Analysis and Regulatory Issues of Student Mobility in the EU, European Journal of Education, 31(2), 205-222.

Raymond, R. \& Michael Sesnowitz, R. (1975). The Returns to Investments in Higher Education: Some New Evidence, The Journal of Human Resources, 10(2), 139-154. https://doi.org/10.2307/144823

Renshaw, E. F. (1960). Estimating the Returns to Education, The Review of Economics and Statistics, 42(3), $318-324$. https://doi.org/10.2307/1926380

Rhoades, G. (1983). Conflicting Interests in Higher Education, American Journal of Education, 91(3), $283-327$. https://doi.org/10.1086/443692

Rhoades, J. L. (1978). The Role of the Student in the Higher Education Production Function, Research in Higher Education, 9(2), 169-179. https://doi.org/10.1007/BF00977398

Robinson, A. J. (1971). Government Subsidy to Higher Education: The Benefits, Costs and Non-Economic Value of the Policy, The American Journal of Economics and Sociology, 30(3), 259-274. https://doi.org/10.1111/j.1536-7150.1971.tb03230.x

Rogers, D. C. (1972). Student Loan Programs and the Returns to Investment in Higher Levels of Education in Kenya, Economic Development and Cultural Change, 20(2), 243-259. https://doi.org/10.1086/450546

Sharma, R. K. (2006). FDI in Higher Education: Official Vision Needs Correction, Economic and Political Weekly, 41(49), 5036-5037.

Stafford, K, L., Lundstedt, S. B., Lynn, A. D., \& Jr, (1984). Social and Economic Factors Affecting Participation in Higher Education, The Journal of Higher Education, 55(5), 590-608. https://doi.org/10.1080/00221546.1984.11780681

Sullivan, T. A., Mackie, C., Massy, W. F., \& Sinha, E. (2012). Improving Measurement of Productivity in Higher Education, The National Academic Press Washington, D.C

Trumbull, W. N. (1990). Who Has Standing in Cost-Benefit Analysis? Journal of Policy Analysis and Management, 9(2), 201-218. https://doi.org/10.2307/3325412

Westerheijden, D. F. (1999). Innovation Indicators in Science and Technology Evaluation: Comments from a Higher Education Point of View, Elsevier Science Ltd, Oxford, 45(3), 445-453.

Wigger, B. U. (2004). Are Higher Education Subsidies Second Best? The Scandinavian Journal of Economics, 106(1), 65-82. https://doi.org/10.1111/j.0347-0520.2004.t01-1-00348.x

Winkler, D. R. (1984). The Costs and Benefits of Foreign Students in United States Higher Education, Journal of Public Policy, 4(2), 115-138. https://doi.org/10.1017/S0143814X00002099

Woodhall, M. (2004). Cost-Benefit Analysis in Educational Planning, Fourth Edition, UNESCO International Institute for Educational Planning

Yousapronpaiboon, K. (2014). SERVQUAL: Measuring higher education service quality in Thailand, Procedia - Social and Behavioral Sciences 116, 1088-1095.

\section{Copyrights}

Copyright for this article is retained by the author(s), with first publication rights granted to the journal.

This is an open-access article distributed under the terms and conditions of the Creative Commons Attribution license which permits unrestricted use, distribution, and reproduction in any medium, provided the original work is properly cited. 